\title{
М.П. Мироненко
}

\section{СУДЬБА РУССКОГО АРХЕОЛОГА НА ПЕРЕЛОМЕ ЭПОХ}

Аннотация Статья посвящена судьбе археолога, историка, сотрудника Румянцевского музея, краеведа, заведующего секцией охраны музеев и памятников искусства и старины в Архангельске, члена и активнейшего участника Архангельского Церковно-археологического комитета и Архангельского общества изучения Русского Севера К.Н. Любарского (1886-1920). В ОПИ ГИМ хранится его архив, проливающий свет на историю его борьбы за охрану погибавших на Севере России в годы революции и гражданской войны церквей и других памятников искусства и культуры, за создание Архангельского краевого музея.

Ключевые слова: К.Н.Любарский, археология, история, Румянцевский музей, краеведение, Архангельск, музейное дело, церкви, охрана памятников.

Summary The article is devoted to the fate of an archaeologist, historian, employee of the Rumyantsev Museum, local historian, head of the section for the protection of museums and monuments of art and antiquities in Arkhangelsk, member and active participant of the Arkhangelsk Church Archaeological Committee and the Arkhangelsk Society for the Study of Russian North K.N. Lyubarsky (1886-1920). The Department of Written Sources of the State Historical Museum stores his archive, which sheds light on the history of his struggle to protect churches and other monuments of art and culture dying in the North of Russia during the revolution and civil war, for the creation of the Arkhangelsk Regional Museum.

Keywords: K.N. Lyubarsky, archaeology, history, Rumyantsev Museum, local history, Arkhangelsk, museum affairs, the churches, protection of monuments.

В Отделе письменных источников Государственного исторического музея (ОПИ ГИМ) хранится личный архивный фонд археолога, историка, кра- 
еведа, музееведа Кассиана Николаевича Любарского (1886-1920) ${ }^{1}$. В нем выделяются два важных и совсем неизученных источника, позволяющих представить себе жизнь и труды этого человека. Первый из них - биографический очерк о Любарском «По дороге к вершине»², написанный с большой вероятностью его теткой Прасковьей Кассиановной Любарской. Именно она в 1928 г. сдала в Исторический музей архив своего племянника, однако далеко не весь, оставив у себя его письма и дневники. Она прекрасно знала все подробности его жизни, и ее очерк очень точен и подробен. Его главная ценность в том, что он содержит обширные, иногда на несколько листов отрывки из дневников и писем Любарского, которые не были переданы в Исторический музей, остались у П.К. Любарской и поэтому до нас не дошли. Они описывают подробности его военной службы, археологических поездок, жизни на Русском Севере, и в этом смысле очерк представляет собой ценный источник для биографии и изучения творческой деятельности Любарского. О другом важном источнике, содержащем работы Любарского, будет сказано позже.

Отец родившегося в 1886 г. в Москве Кассиана был французом, но брак родителей распался, и Кассиан носил фамилию матери, а отчество по дяде, крестному отцу. Закончив Московское реальное училище К.П. Воскресенского и юридический факультет Московского университета, он служил в МАМЮ, а затем в Румянцевском музее. С юных лет и до своей трагической гибели в августе 1920 г. больше всего он любил русскую старину и археологию. Эта любовь во многом сложилась под влиянием его тетки, Прасковьи Кассиановны Любарской, учившейся на Московских высших женских курсах и бывшей ученицей Ф.И. Буслаева, с которым она состояла в переписке и дружеских отношениях. Семья Любарских происходила из Рязани, и там находился их родовой дом. Касьян (Кассиан) стал членом Рязанской губернской ученой архивной комиссии и издал «Краткий обзор ризницы Рязанского архиерейского дома» (Рязань, 1912) и «Рязанский некрополь (Спасский мужской монастырь. Ч. 1)» (Рязань, 1914), собирал книги и предметы старины для создания в Рязани музея Рязанской ученой архивной комиссии. Летом 1914 г. он представлял Рязанскую губернскую ученую архивную комиссию на XVI Археологическом съезде в Пскове, но из-за начала войны съезд был отменен, и участники съезда могли только наблюдать панику на вокзале в Пскове.

1 Изучение архивных материалов К.Н. Любарского проводилось в рамках проекта РФФИ № 16-01-00342-ОГН.

2 ОПИ ГИМ. Ф. 315. Оп. 1. Д. 1. Л. 1a-96. 
В 1913 г. Любарский совершил поездку по Туркестану, во время которой он фотографировал исторические памятники и составил альбом фотоснимков, хранящийся ныне в отделе ИЗО в ГИМ. Он был членом Комиссии по изучению старой Москвы при Московском археологическом обществе, членом Тульской палаты древностей. Летом 1915 г. с хранителем Отделения доисторических, христианских и русских древностей Румянцевского музея С.О. Долговым был командирован на Кавказ для археологических раскопок, осмотра, снятия обмеров и фотографий древних памятников Кавказского края и приобретения предметов древности для музея. Во время этой командировки Любарский вел дневник с фотографиями раскопок и памятников и оставил путевые записки «Кавказское побережье»³.

Вернувшись с Кавказа, он искал для себя такое поле деятельности, чтобы приносить пользу обществу, и нашел: работал в организациях по приему беженцев, в детских столовых, устраивал концерты для раненых в госпиталях и, наконец, работал в Красном кресте по оборудованию и отправке транспортов в окопы передовых линий.

В феврале 1916 г. Любарский был призван в армию. Хотя он по закону мог отказаться от службы как единственный сын, но присущее ему чувство долга не позволило сделать это, он прошел военное обучение в качестве вольноопределяющегося и как знающий иностранные языки был направлен служить в Архангельское Главное артиллерийское управление, заниматься отправкой военных грузов, получаемых от союзников, водным путем. Во время взрыва боеприпасов на пароходе «Барон Дризен» в Архангельске он был ранен и чуть не лишился зрения. В начале 1917 г. он был направлен в командировку в Мурманск для отправки военных грузов по незамерзающим рекам (Кола, Северная Двина). Там 3 марта 1917 г. его встретило известие о Февральской революции, которому он был искренне рад. «Воображаю, как кипит, бурлит жизнь у вас теперь! Сколько новых горизонтов, новых возможностей, новых работ и применения сил!» - писал он родным ${ }^{4}$ Его глубоко поразило известие об артиллерийском обстреле Кремля, о самом факте, что на него подняли руку. «Люди всегда зверели во все революции. Думается, что разгромом Кремля большевики очень себе повредили в стране, где теории так мало значат, а нужны факты. Это неопровержимо, и многих вероятно приведет в ужас. Скоро наступит крах, и придет новая полоса в жизни», — надеялся он ${ }^{5}$.

\footnotetext{
3 Дневник «Кавказская поездка летом 1915 г.». Ч. 1, 2; Путевые записки «Кавказское побережье» // Там же. Д. 2-4.

4 Там же. Д. 1. Л. 55.

5 Там же. Л. 73-74.
} 
В Архангельске Любарский стал деятельным членом губернского Церковно-археологического комитета и Архангельского общества изучения Русского Севера, ездил по Архангельскому уезду для осмотра и снятия чертежей и фотографий с разрушающихся деревянных церквей, посещал отдаленные скиты, занимался в архивах. В фонде Любарского хранится его «Краткий отчет о поездке по Архангельскому уезду летом 1919 г.» (с чертежом церкви в с. Солуне) и удостоверение, выданное К.Н. Любарскому и заведующему Художественной студией писателю и этнографу С.Г. Писахову о том, что они командированы в с. Заостровье для осмотра, взятия на учет и вывоза предметов старины для краевого музея (14 мая 1920 г.). Любарский писал статьи по истории Русского Севера, основанные на изучении архангельских архивов («Крестьяне Архангельской губернии в XVII столетии», «Материалы по истории быта, экономической и государственной жизни России в XVII столетии», «Лопарские клейма», «Прогулка по Москве XVII столетия с монахами Сийского монастыря: (Опыт живописной систематизации материалов)», «Некоторые черты из деловых поездок монахов Сийского монастыря в Москву в XVII столетии»), которые он публиковал в местных изданиях (главным образом, в «Известиях Общества изучения Русского Севера»), читал для солдат в клубе лекции по истории с волшебным фонарем. Кроме того, он, как хорошо знающий французский язык, был прикомандирован к находившейся в Архангельске Французской военной миссии. Он был неустанным пропагандистом идеи охраны памятников старины на Русском Севере, с настоящей болью писал о разрушающихся деревянных церквях, о гибели помещичьих библиотек, о вывозе пудами за границу икон и рукописей. А главной целью его жизни стало создание Архангельского краевого музея, чему он посвящал все свои силы, в то время как охваченное тяготами гражданской войны даже образованное общество было довольно глухо к его призывам. Он работал за десятерых, пытался побудить окружающих музейщиков также работать в полную силу, пользовался всяким случаем, чтобы проводить свои идеи о пользе музеев и книжности и их огромном значении в жизни государства, старался пополнять коллекции будущего музея.

В ОПИ ГИМ хранится переплетенный том, составленный самим Любарским из автографов его многочисленных докладов, статей, заметок, писем по музейному делу и по поводу спасения памятников старины и искусства, которыми он бомбардировал различные руководящие организации ${ }^{6}$. Лист использования был пустым, видимо, никто не открывал его, кроме обрабатывавших фонд архивистов. Обложка любовно оформлена Любарским, заголовок вы-

${ }^{6}$ ОПИ ГИМ. Ф. 315. Оп. 1. Д. 5. 
веден тушью псевдо-руническими буквами: «Выброшенное в суету жизни». Главное содержание этих материалов - отчаянная борьба Любарского за создание в Архангельске Краевого музея Северного края. В работе «Охрана памятников искусства и старины» он писал: «По мног[им] историч[еским] и географич[еским] прич[инам] Арханг[ельск] имеет возм[ожность] создать у себя образцовый, исключит[ельный] по богатству и знач[ению] госуд[арственный] кр[аеведческий] м[узей], кот[орым] здесь, в портовом городе и центре обширн[ого] края, могли бы гордиться и правит[ельство], и населен[ие], и реальная госуд[арственно]-экономич[еская] роль кот[орого] была бы неоценима» ${ }^{7}$. Существовавший же городской музей, как писал Любарский в другой имеющейся в томе работе «Музей местной старины» (1918), не имея ни денежных средств, ни официальных полномочий, влачил печальное существование. Он был лишен возможности приобретать гибнущие на местах из-за невежества или скупаемые ловкими агентами для перепродажи за границу исторические материалы, и вынужден был перебираться из одного неудобного помещения в другое, еще менее подходящее. Не было возможности ни пополнять коллекции, ни проводить экскурсии, ни издавать труды. Любарскому удалось в 1918 г. получить согласие духовных лиц на передачу новому Краевому музею флигеля духовной семинарии. После небольшого ремонта и переселения жильцов это здание вместило бы в себя ютившиеся в неприспособленных помещениях небольшой городской музей и музейные коллекции Церковно-археологического комитета, собранные, как он искренне отмечал, не «благодаря чему-либо», а «несмотря ни на что».

Среди материалов тома - программный доклад «Значение археологии и областных музеев в жизни государства», читанный Любарским на заседании Общества изучения Русского Севера 29 декабря 1918 г., в котором он излагал принципиальную необходимость создания музея: «давно уже пора (и дай Бог, чтобы не поздно), настоятельно необходимо для самого нашего существования если не всему населению, то хоть части его, понять, что процветание государства без процветания науки немыслимо. Не можем мы, неучи, конкурировать с теми, кто вооружен всеми доступными человеку знаниями. В лучшем случае русская наука подвигалась вперед, запертая в стенах учреждений, доступная лишь тем, кто... ей посвящает всю жизнь. Но для государства этого еще далеко не достаточно. Категорически необходимо, чтобы наука раскрывала свои знания для широких масс, чтобы вся нация пользовалась плодами ее открытий» ${ }^{8}$.

\footnotetext{
7 Там же. Л. 145.

8 Там же. Л. 12.
} 
В мае 1918 г. им был подготовлен «Доклад Архангельскому губ[ернскому] комиссару народного просвещения о значении, положении и нуждах областного Церковно-археологического музея». Осенью 1919 г., когда войска союзников готовились покинуть Архангельск, встал вопрос о возможной эвакуации коллекции музея Церковно-археологического комитета. Любарский написал короткое, но выразительное «Ходатайство перед Временным правительством (Археологического комитета)», где указывал, что музей содержит драгоценные собрания рукописей и грамот (30 тыс. документов, книги, собрания икон и других церковных предметов в количестве 800 номеров, представляющих собой «незаменимую историческую и культурную ценность огромного общерусского значения» (подчеркнуто Любарским. - M.M. $)^{9}$. К счастью, эвакуация не состоялась.

В докладе «Нужды момента» (январь 1920 г.) он писал: «Пудами и вагонами вывозятся из России различные культурные ценности... Чужие страны, собравшие уже немало образцов русского искусства, положат их в свои музеи, и мы, чтобы изучать их, поедем в Германию, в Америку, в Англию... Обидно и глупо» ${ }^{10}$. Доклад был одобрен Обществом изучения Русского Севера, и было решено обратиться к правительству с предложением издания закона об охране памятников, имеющих государственное значение. В работе «Государство и музеи» Любарский выдвигал задачу создания сети широко поставленных, постоянно пополняемых и внимательно следящих за жизнью страны музеев с отделами естественных богатств и прикладных знаний. Его излюбленным аргументом, доказывающим необходимость музеев, была их важная роль в восстановлении исчезавшей местной промышленности, ремесел, народного искусства. Любарский возлагал большие надежды на идею государственного плана возрождения русского искусства через показ лучших образцов в музеях. Не раз писал он о том, что музей должен быть не складом старых любопытных вещей, предметом роскоши в государстве, а живым действенным организмом. В работе «Старожилам Архангельска» он призывал местных жителей помочь созданию музея и для раздела истории Архангельска приносить книги, письма, воспоминания, портреты и рисунки, фотографии, вещи, костюмы и проч.

В «Докладе в Москву о задачах, состоянии и нуждах Краевого музея гор[ода] Архангельска» он говорил о том, с каким трудом идет создание музея, о провинциализме, сепаратизме музейных работников, непонимании государственных задач. Не было людей - все были призваны на во-

9 Там же. Л. 28 об.

${ }^{10}$ Там же. Л. 70 об. 
енную службу, не было средств, связь с местными провинциальными музеями была плохая. «Словом, каждому археологу и музееведу знакомая еще по прежним временам картина, но, пожалуй, сгущенная в красках, п[отому] ч[то] теперь больше надежд и мечтаний», — с грустью заключал он ${ }^{11}$.

«Будем приучать себя не проводить ни одного дня, ни одного часа без пользы для общего блага», - писал он. Призывал к деятельной, созидательной работе на новых государственных и социальных началах, которые, как он искренне верил, теперь, после падения самодержавия, установятся в России, поскольку «в настоящее время... возрождается русская общественная жизнь и перестраивается на демократических началах под знаменем народного самоопределения». В Архангельске, как и на всем Севере России, в 1918-1919 гг. находились войска Антанты, действовало их Временное правительство, и связь с остальной Россией была весьма затруднена, хотя письма доходили, хоть и нерегулярно. Видимо, этим частично можно объяснить несколько наивное и преувеличенно оптимистичное представление Кассиана Николаевича о действительном положении дел в стране.

Любарскому приходилось бороться с равнодушием, ленью, непониманием окружающих. Он писал: «Никогда еще, ни в одном городе, не видел я более печальных условий существования [Археологического] к[омите]та и его М[узея] и более упорного, стойкого равнодушия общества, где даже, кажется, самый факт существования М[узея] едва лишь признается терпимым» ${ }^{12}$. Его охватывало чувство отверженности от окружавших его людей. В апреле 1918 г. он писал: «За последнее время мне часто здесь делается страшно. Кажется, что люди, как голодные собаки, накинутся на меня и разорвут, потому что от меня иначе пахнет. Я думаю и чувствую не так как все здесь; живу в непонятной, а потому смешной для них и часто неприятной плоскости. С каждым днем все это острее. Минутами нападает такой страх, что я готов спрятаться Бог знает куда. Лучше всего чувствовалось бы у французов, за гарантирующими, от всего изолирующими стенами миссии, если бы не остатки патриотизма, выражающегося в чувстве стыда перед ними... Ни во что не верится, все кажется грязным, призрачным... Кроме прошедшего, к которому еще больше начинаю обращаться, за невозможностью смотреть вперед. Это уже новый вид археологии. Так сказать, археология поневоле» ${ }^{13}$.

Любарский неплохо знал членов Французской миссии, к которой был прикомандирован. Получив для музея флигель семинарии, он предложил

\footnotetext{
${ }^{11}$ Там же. Л. 143.

12 Там же. Л. 12.

${ }^{13}$ ОПИ ГИМ. Ф. 315. Оп. 1. Д. 1. Л. 81-82.
} 
временно размещать там французов, возвращавшихся на родину, водил их в музей и рассказывал о русской истории. В томе его работ сохранились его речь, произнесенная при вручении ему французского военного креста и тост на праздновании Нового года. Покидавшие осенью 1919 г. Архангельск члены Французской миссии неоднократно официально и весьма настоятельно приглашали его уехать с ними во Францию и гарантировали там работу. Однако, считая текущий момент «слишком важным для России и открывающим такие широкие перспективы для его излюбленной деятельности» ${ }^{14}$, Любарский не счел возможным бросить родину и отказался от эмиграции.

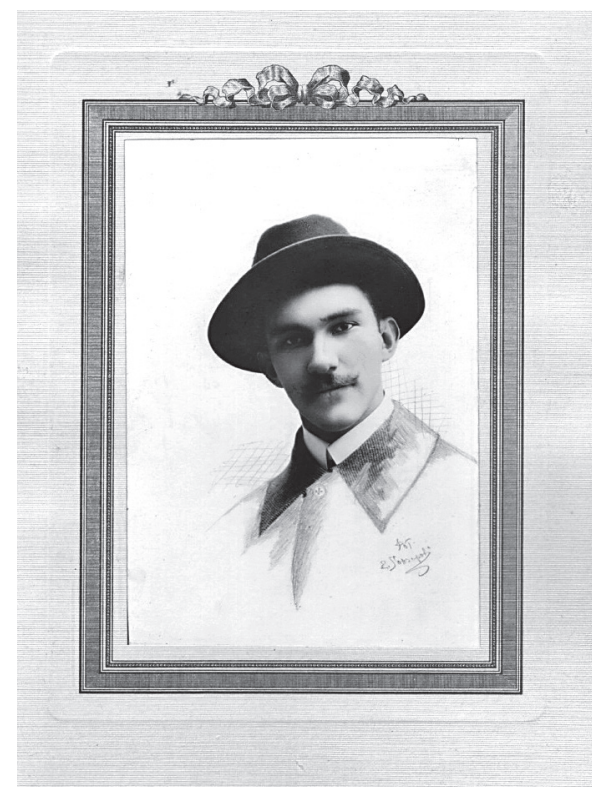

Кассиан Николаевич Любарский.

ОПИ ГИМ. Ф. 315. On. 1. Д. 1.

В марте 1920 г. он был назначен заведующим секцией музеев и охраны памятников искусства и старины при Архангельском губернском отделе Наркомпроса. Казалось бы, теперь для него открылись все возможности для воплощения идеи, которой он отдал столько сил. Однако исторические события, развивавшиеся на Российском Севере, привели к совсем другому повороту его судьбы.

\footnotetext{
${ }^{14}$ Там же. Л. 96.
} 
После установления советской власти в Северном крае К.Н. Любарский 26 июля 1920 г. был арестован. Его обвинили в том, что якобы летом 1918 г. при высадке союзников он утопил в реке замки от орудий красноармейских частей и сообщил о месте потопления союзникам. Единственным косвенным доказательством его вины были его связи с Французской миссией и вручение ему французского военного креста. По постановлению Архангельской ВЧК он был расстрелян 7 августа 1920 г. Хранящиеся в дневниках и статьях Любарского высказывания об иностранных интервентах делают подобные обвинения невозможными. «Ох уж эти мне союзники! Авантюра сменяет другую. Ни плана, ни цели, ни, главное, соглашения между собою. Полное недоверие», — писал он по поводу распоряжений союзников, занявших Архангельск в августе 1918 г. «Я вполне убедился в эгоистической неискренности “союзников” по отношению к России... В массе все это была преподлая авантюра». «Если никакие иностранные “благодетели” не ввяжутся в наше дело, то, может быть, все и пойдет на лад, к быстрому улучшению. Задатки, по-моему, для этого есть», — продолжал он ${ }^{15}$. В статье «Требование ответственного исторического момента», посвященной необходимости создания Книжной палаты, одной из целей которой он считал сохранение редких местных изданий, в том числе выходивших в годы гражданской войны, он с насмешкой задавал вопрос: «А где найдем мы теперь висевшие в свое время на каждом углу широковещательные объявления, приглашавшие добровольцев в иностранные легионы?.. А где достать теперь 1-2 экземпляра русских приказов, предлагавших жителям “исполнить свой гражданский долг и выйти навстречу союзным войскам для выражения радости по случаю их прихода?"» ${ }^{16}$.

Любарский оставил завещание, в котором выражал желание подарить свой семейный дом в Рязани городу для устройства в нем «на вечные времена» музея Рязанской губернской ученой архивной комиссии. Им было собрано в течение всей жизни много предметов для этого музея и 300 книг. Если же, как он опасался, по каким-то причинам разместить там музей не получится, то он предлагал устроить в доме городскую читальню-библиотеку имени Любарских. Но дом был отнят, много вещей пропало, часть вещей была продана матерью и теткой, которым не на что было жить. Через год после гибели Любарского его мать ездила в Архангельск, чтобы разузнать подробности дела, но ничего нового ей не сообщили. Узнала она только, что в городе не осталось ни одной семьи, где бы ни было погибших.

\footnotetext{
${ }^{15}$ Там же. Л. 89, 90 об.

${ }^{16}$ ОПИ ГИМ. Ф. 315. Оп. 1. Д. 5. Л. 132 об.-133.
} 